European journal of American studies

Special Issue: Race Matters: 1968 as Living History in the Black Freedom Struggle

\title{
Race Matters: 1968 as Living History in the Black Freedom Struggle
}

Jorrit van den Berk and Laura Visser-Maessen

\section{OpenEdition}

\section{Journals}

Electronic version

URL: https://journals.openedition.org/ejas/14233

DOI: 10.4000/ejas.14233

ISSN: 1991-9336

Publisher

European Association for American Studies

Electronic reference

Jorrit van den Berk and Laura Visser-Maessen, "Race Matters: 1968 as Living History in the Black Freedom Struggle", European journal of American studies [Online], 14-1 | 2019, Online since 29 March 2019, connection on 08 July 2021. URL: http://journals.openedition.org/ejas/14233 ; DOI: https:// doi.org/10.4000/ejas.14233

This text was automatically generated on 8 July 2021.

Creative Commons License 


\title{
Race Matters: 1968 as Living History in the Black Freedom Struggle
}

\author{
Jorrit van den Berk and Laura Visser-Maessen
}

1 The social and political movements that rocked the world just over half a century ago touched upon issues so fundamental to contemporary society, culture, and politics that the dust has yet to settle. ${ }^{1}$ In fact, every generation that followed the year 1968 has looked back to find new lessons, unresolved issues, and enduring legacies. As Giles Scott-Smith notes, uncovering the significance of that year-and by extension the full decade-has become "a mini-industry in itself." A little over ten years ago, when the very first special issue of this journal marked the 40th anniversary of 1968, scholars mapped transnational linkages tying the demands of the global South to the protest cultures of the North; discussed an enduring conservative backlash against the New Left; and identified the lasting legacies of 1968 in the work of the American Studies community in terms of research and teaching. Indeed, these themes continue to inspire important and innovative research. ${ }^{2}$ At the same time, new questions about the legacies of 1968 and the 1960s in general are presenting themselves to us, as scholars and as citizens, ever more urgently. This is particularly true of race and racial struggle, as unresolved race matters from the past intersect with twenty-first century activism aimed at countering the continued devaluation of black lives.

2 This special issue of The European Journal of American Studies therefore centers on the black freedom struggle to explore how those "unresolved race matters from the past" weigh down on the present. Articles focus on specific events in 1968, the way they shaped the present or how they are remembered or framed in the present by scholars, activists, and their opponents. As argued below, there is a notable tendency among activists and scholars today to focus on the black, and especially radical, activism of the late 1960s. The goal is thus not to imply that the year 1968 was inherently different or more important than any year preceding or following it, but to explain why and categorize how today's racial status quo has shaped contemporary societal and scholarly interest in that specific moment in the black freedom struggle. To facilitate this endeavor, this introduction relates the racial struggles of 1968 to those of the 
present (section 1) and show how these connections tie into the developing academic literature on the black activism of the $1960 \mathrm{~s}$ and the $21^{\text {st }}$ century (section 2). The final section outlines the individual articles that make up this special edition and their relevance in these current academic and societal debates, particularly with regard to (dis)continuities in political activism, protest cultures, backlash, and memory in relation to the ongoing black freedom struggle (section 3 ).

3 To understand why and how contemporary scholars and activists engage the year 1968 in their interpretation of the black freedom struggle, it is imperative to first outline how race matters today. In fact, a key demand of protest groups such as Black Lives Matter is for the universal recognition that race still matters. While this may seem like an open door to those activists and scholars who have devoted their careers to the exposure of racial and racist structures, the recent emergence of a new generation of black activists (a transatlantic phenomenon as noted below) must largely be understood in the context of the general sense of complacency about race matters that characterized many western nations only ten years ago.

4 After all, in the United States, the $40^{\text {th }}$ anniversary of the year 1968 also marked the election of the first black president of the United States. When Barack Obama entered the White House, commentators across the political spectrum-albeit for different reasons-welcomed a new dawn in race relations, as the election erroneously "confirm[ed] the view of many, especially whites, that the United States is a postracial society." ${ }^{3}$ The president himself offered a more tempered view and attempted to educate a larger electorate about the complexities of race, America's racial past, and the unfinished work of the civil rights movement. ${ }^{4}$ At the same time, Obama celebrated the tangible victories of that movement, such as legislative milestones, and emphasized comparable gains made since that time. He framed the struggle as being near completion, with its remaining "10 percent" to be solved mainly through black personal responsibility. ${ }^{5}$ By subscribing to what Jeanne Theoharis terms the "seduction of the almost-there," he joined a long line of politicians and commentators from both parties who used and still use the memory of the civil rights movement as a "national redemption song." Yet framing the movement as a sign of progress that validates the strength, validity, and uniqueness of American democratic values, Theoharis believes, only encourages the maintenance of the status quo, while it should serve as a reminder to deal adequately with its fundamental charge of continuous systemic racism as America's "original sin."

5 Indeed, both scholars and a new generation of activists have criticized and distanced themselves from the 'post-racial' narrative that surrounded Obama's election. In fact, the current wave of black activism cannot be separated from either. For example, many young black college graduates-whose presence represents one of the most visible gains of the 1960s movement-became politically active during the Obama administrations. Their political worldview was shaped in part by the perception that Obama's faith in American exceptionalism did not square with the reality that the 2008 economic crisis affected them more badly than their white counterparts. ${ }^{7}$ Black millennials, moreover, had shown great enthusiasm for Obama's candidacy, but were disillusioned by what they perceived as the president's failure to forcefully address the economic crisis and police brutality against young blacks. ${ }^{8}$ Subsequently, in line with the protest movements of the 1960s, many young activists are again increasingly willing to achieve change as much outside as within the accepted norms of protest. ${ }^{9}$ 
"Until there was a black Presidency, it was impossible to conceive of the limitations of one," Jelani Cobb poignantly summed up. Obama "[was] determined that he could bring about change more effectively through electoral politics; [Black Lives Matter cofounder Alicia] Garza is of a generation of activists who have surveyed the circumstances of his Presidency and drawn the opposite conclusion." ${ }^{10}$

6 Against this background, many scholars also seek to make sense of Obama's mixed record on race matters. Urging his readers to move "beyond the haters and hagiographers," Michael Eric Dyson for example offers a balanced assessment of Obama's achievements in his book The Black Presidency (2016). Among others, Dyson highlights Obama's struggle for the Affordable Care Act, the way in which he bore "the burden" of representing blackness in America, and his efforts to fight segregation in housing and discriminatory policing late in his second term, all while contending with racially tinged criticism of his opponents. "Obama is an extraordinary figure who has done some good things in bad times, and some great things under impossible circumstances," he concludes. Yet Dyson also criticizes Obama for neglecting to respond to crises such as the protests in Ferguson with a more acute analysis of race relations in the United States-one that could have "provided a compelling alternative to [Trump's] vision." 11

7 Dyson's criticism represents a growing trend among left-leaning scholars, particularly black ones, who believe that the significance of obama's presidency for black Americans should not prevent a critical evaluation of his actions. While symbolic acts in response to specific problems-such as the "beer summit" with Henry Louis Gates following the latter's unjustified arrest-may be important, he largely left questions of institutionalized racism untouched. He thereby helped, in Theoharis's words, to perpetuate the "structured blindnesses" in America's "national fable" of upwards racial progress. ${ }^{12}$ In another example, Ta-Nehisi Coates praises him for his help of black farmers, his Justice Department's sensitivity to uncovering racial disparities in criminal justice, and for the power of the Obamas as the "symbol of black people's everyday, extraordinary Americanness." However, he unequivocally faults the president for trusting too much in the "goodwill" of the nation, to the extent that "he ultimately believed [his country] to be a force for good in the world...obama, his family, and his administration were a walking advertisement for the ease with which black people could be fully integrated into the unthreatening mainstream of American culture, politics, and myth. And that was always the problem." ${ }^{13}$ Other black intellectuals have followed suit with even more intense critical analyses. Keeanga-Yamattha Taylor emphasizes how "the roots of the current movement against police brutality [can be traced to] the raised expectations of the Obama campaigns, as well as Obama's ensuing silence on the critical issues facing African Americans." The "post-racial' narrative combined with the visible success of individual black Americans like the Obamas, she charges, then worsened those conditions, as they are "used to justify dismantling the state's capacity to challenge discrimination." ${ }^{14}$

8 Thus, we are now surveying the academic field from what might be called an unnerving 'post-post-racial' present. Matters of race and black lives are again at the forefront of societal and scholarly debates, as narratives of progress, successes, and failures are increasingly unsettled. ${ }^{15}$ Scholars and activists alike are revisiting the past from this vantage point and have found that the turmoil of the late 1960s and 1968 in particular is an apt window into contemporary race relations. This of course does not mean that 
today's realities are essentially those of half a century ago or that interpreters of the present should not be wary of "how 1960s-oriented frameworks run aground when applied indiscriminately to narratives of racial violence in the new millennium." 16 However, by holding up the struggles of 1968 as a mirror to the present, persisting racial inequalities are highlighted as well as the ways in which the 1960 s continue to inform and inspire explanations of and resistance to the status quo in the $21^{\text {st }}$ century. After all, as Mark Twain allegedly quipped, "history doesn't repeat itself, but it often rhymes."

\section{It Rhymes: Reverberations of 1968}

9 As for many other protest movements, 1968 was a crucial year in the development of the black freedom struggle. While the judicial and legislative gains of previous years were implemented at the national and local level in the United States, emboldened activists and ordinary citizens continued to confront festering social problems as well as the hegemony of white, mainstream culture. The Fair Housing Act was established by Congress and the Supreme Court made careful moves forward in school integration with its decision in Green v. County School Board of New Kent County. But schoolboards and white teachers in places like Ocean Hill-Brownsville squared off with black residents who demanded community control over schools, while Pan-African nationalists experimented with independent education. A sweeping, multiracial Poor People's Campaign inspired the building of a 'tent city' of 3,000 residents on the Washington Mall. Black Panthers and other activists confronted heavily armed police forces as well as the Federal Bureau of Investigation (FBI), which targeted black organizations that it deemed "subversive" under the COINTELPRO program. Protests that turned violent grabbed headlines on a frequent basis, especially surrounding the Orangeburg Massacre, the Democratic National Convention, and the trial of the 'Chicago Seven.' Part of a wave of urban unrest that characterized the 1960 s as a whole, the assassination of Martin Luther King, Jr. Left mass destruction, injury, and death in its wake when riots swept over more than a hundred urban areas. ${ }^{17}$ On the cultural front, the Black Arts Movement (BAM) was in full swing, the first Black Studies programs were established, and the Black Power salute gained worldwide recognition after the Mexico Olympics. International developments were important in other ways too, as black leaders continued to strengthen the movement's involvement with US foreign relations and anti-colonial struggles. For example, Martin Luther King had strongly denounced the Vietnam War with his seminal "Beyond Vietnam" speech in 1967. Around the same time, Stokely Carmichael (Kwame Turé) traveled to Europe, Africa, and the Caribbean. In 1969, he permanently left the US for Guinea, where he became a spokesman for pan-Africanism. ${ }^{18}$

10 Meanwhile, fatigue with racial unrest coincided with a growing desire among the general population for an end to the social and political upheavals that also accompanied many of the other 'rights revolutions' of the decade. Moderate and more conservative politicians increasingly campaigned on law and order, often using a 'colorblind' rhetoric that evolved into the 'post-racial' narrative that is still with us today. Movement activists at the time struggled to come up with an effective response, especially because a growing segment of the black middle class joined such calls. These included teachers, preachers, judges, police chiefs, and politicians who were ready to 
join the electoral playing field opened up by the 1965 Voting Rights Act or to reestablish themselves as the gatekeepers of the race. ${ }^{19}$ The presidential election of Richard M. Nixon became the opening salvo of a new conservative era. Whether Nixon himself can be considered a conservative is up for debate, but several of his tactics, such as the southern strategy, became useful tools for future conservative candidates to counter the gains of the 1960s black freedom movement and the expansion of the postwar welfare state. As a result, the dream of a full-scale "revolution of values" that Martin Luther King had consistently called for in the final year of his life was never to be realized. ${ }^{20}$

The legacies of 1968 are very much with us today. They continue to assert themselves as living history on many fronts: from the interpretations of and actual responses to current events by politicians, activists, and ordinary citizens on a local, national, and international scale to the scholarship that arose as a consequence of the establishment of Black Studies programs. Moreover, they are reflected in the inspiration, memory, and mythmaking drawn from that time that inform present-day (perceptions of) race relations and black activism. These in turn shape interpretations of "the path from 1968 to Trump's election" that scholars, activists, and critics (ab)use to explain, justify, or resist today's status quo. Samuel Moyn's recent criticism of Mark Lilla's popular book The Once and Future Liberal (2017), which seeks to explain why American liberals continue to lose ground to rightwing and populist movements, is a case in point. According to Moyn, Lilla pays too little attention to the role of economics and politics in the creation of structural inequalities when he criticizes the Left for stubbornly clinging to the identity politics of its late 1960s predecessors. Far more important, in Moyn's view, is the way in which free market ideology came to dominate the entire political spectrum with the 1968 "crossroads, when neoconservatism and neoliberalism arrived." The answer to Trump then, is not Lilla's insistence that "spokespeople for oppressed groups...soft-pedal their indictments of white supremacy for strategic purposes, so long as white males are needed for Democrats to win elections," but a "contemporary New Deal" program that truly addresses structural justice for all and ensures that "markets serve more than the rich."

How the '1968-to-Trump' narrative is understood thus impacts the solutions that scholars, activists, and politicians seek for the current state of affairs, which includes an increasingly grave social reality for many racial and ethnic minorities. Recent studies have convincingly shown that structural racism, that is, disparities between black and white Americans that have become institutionalized, continues to shape American society. This is visible in the overrepresentation of (young) black males in prison populations and the effects of felony disenfranchisement on the black electorate ${ }^{22}$; the consequences of historic structural injustices (including redlining, resistance to school integration, gentrification and white flight, among others) that have now cemented ghettoes as a perpetual-rather than a mere provisional-fixture in the American landscape ${ }^{23}$; decreased accessibility to the electoral process due to gerrymandering, voter repression tactics, and court-cases like Shelby County v. Holder (2013); and continued racialized calls for 'law and order' and military-style policing of black communities that were set in motion by the Omnibus Crime Control and Safe Streets Act of 1968 and other measures adopted as a response to black protest. ${ }^{24}$ What is more, despite clear improvements in income, college graduation rates, and overall life 
expectancy, it is striking how many markers of progress have returned to-or even exceed-(pre)1960s levels, like in school segregation, racial wealth disparity, and the declining state of the black family as measured by, for example, decreased financial security and an increase in female headed households. ${ }^{25}$ Even the government's and public's response to the current national opioid crisis reveals the enduring disparity between black and white addicts in terms of provided empathy, available treatment, and punishment that largely date back to these law-and-order campaigns and the subsequent War on Drugs of the 1970s and 1980s. ${ }^{26}$

These unresolved tensions of the past and new ones are now bursting into the open. Groups like Black Lives Matter (BLM) and the Movement for Black Lives (MBL), a nationwide coalition of over 50 organizations aimed at representing and ameliorating the grievances of black communities, have brought the continuing problems of police brutality, state-sponsored violence and surveillance, economic injustice, and lack of community control back to attention. The same is true for the protests in Ferguson, Baltimore, and elsewhere, some of which were accompanied by violence. The latter has revived 1960s debates among activists and scholars over the "politics of respectability," that is, the belief that adherence to accepted, often middle class, norms of behavior and protest will lead to inclusion in mainstream society, and whether to see violent upheavals as a sign of criminality or a form of political action. ${ }^{27}$ Likewise, groups like MBL echo criticisms in the black radical tradition, articulated most notably in the 1960 s in relation to the war in Vietnam by the Black Panther Party, the Student Nonviolent Coordinating Committee (SNCC), and Martin Luther King, of what Aziz Rana has labelled "national security citizenship"-the notion that minority groups can "earn inclusion" through the embrace of military service and American foreign policyparticularly when this support comes at the expense of solidarity with other marginalized groups around the world. ${ }^{28}$

Within the United States, such solidarity with "the oppressed everywhere" is now replicated in a new wave of 'rainbow movements,' predominantly against economic, social, and racial injustice (e.g. Fight for $\$ 15$; the New Poor People's Campaign; Moral Mondays; Equal Justice Initiative; prison reform organizations), environmental racism (e.g. Dakota Access Pipeline; the Environmental Justice Movement), the deportation of undocumented immigrants (e.g. United We Dream; the Dream Defenders), and a host of other issues ranging from free speech on campuses to sexual harassment and gun violence. Martin Luther King's nine-year-old granddaughter even gave his vision a contemporary twist by pronouncing her dream of "a gun-free world" at the National Mall during the 2018 March for Our Lives. ${ }^{29}$

In the cultural field, the artistic expressions, protest cultures, and radical symbolism of 1968 have gained renewed currency. The 1960s Black Arts Movement has inspired a new generation of artists, while the anthem protests of NFL athletes such as Colin Kaepernick fit a tradition of athletic activism that includes Tommie Smith and John Carlos' Black Power salute at the 1968 Olympics-topics that are further developed in the contributions to this special issue of, respectively, Jeffrey Ogbar and Douglas Hartmann. Over the past few years, the cultural representations and symbolism of 1960s Black Power activism also reached large and even international audiences through venues like the London Tate Museum's 2017 "Soul of a Nation: Art in the Age of Black Power" exhibition and mass media events such as Beyoncé's 2016 Super Bowl performance. Beyoncé's rendition of her song "Formation" for the halftime show, 
featuring a dance crew sporting Afros and dressed in leather jackets and black berets, was reported to be a tribute to Black Lives Matter and the $50^{\text {th }}$ anniversary of the founding of the Black Panther Party. The performance was both celebrated as a political act and denounced as divisive and anti-police in the mainstream media. ${ }^{30}$ It also renewed debates among scholars who have raised concerns about the silencing of black artists who celebrate their history, as well as debates on the commodification of Black Power by black artists. ${ }^{31}$

hile, responses to current activism, even at times from well-meaning whites, blacks, and movement veterans, mirror the resistance activists in the 1960s encountered. Both generations of activists, Theoharis reminds us, were and are "accused of being reckless, unreasonable, and inflexible, out for their own gain, and unAmerican." ${ }^{32}$ The latter has translated among others in renewed forms of state repression of black activism, with the FBI even introducing the term "black identity extremism" as a category of domestic terrorism threats, a move reminiscent of its 1960s COINTELPRO program. ${ }^{33}$

Paralleling the shift from idealism to disillusionment and white backlash in the 1960s, the high optimism surrounding Obama's election has dissipated within ten years. ${ }^{34}$ It has now been replaced by a shocking spike in hate crimes and emboldened white nationalist organizations, with the 2017 deadly clashes in Charlottesville as a tragic low point. ${ }^{35}$ How the election of Donald Trump fits into this development is a much-debated question. Ta-Nehisi Coates has for instance dubbed Trump "the first white president" because he is the first president "whose entire political existence hinges on the fact of a black president." Drawing an implicit parallel with the Nixon election, he argues that Trump was elected by a new 'silent white majority' to undo Obama's political accomplishments. While acknowledging that Trump voters can be many things at once, he argues that explanations emphasizing economics or resentment of a "condescending Washington elite" do not account for his widespread support among whites from all demographics. Furthermore, those explanations downplay his supporters' willingness to accept Trump's racist pronouncements and policies as collateral damage. As such, alternative explanations for Trump's victory help muddy the waters so "no deeper existential reckoning would be required." ${ }^{36}$ Coates's blunt analysis has met with abundant praise as well as equally blunt dismissals from commentators with a variety of political backgrounds. For example, self-proclaimed "anti-Trump conservative" David French criticizes Coates for overemphasizing racism and for not taking into account voters' dislike of Hillary Clinton; fundamental disagreements over Obama's policies, most notably concerning health care; and Obama's favorability ratings by the end of his second term. ${ }^{37}$ Whereas it may be too early to come to a balanced assessment of the causes and consequences of Trump's election, it is fair to say that the debate over the degree to which racism was a factor in itself illustrates the difficulty of discussing race in an allegedly post-racial world.

While the above has centered on the United States, it is important to note that the larger issues raised here are pertinent for other parts of the world that grapple with similarly unresolved and unsettling legacies from their racial histories, as also shown in the article by Laura Visser-Maessen in this edition. For example, US debates surrounding the taking down of Confederate statues are mirrored in Europe, where Afro-European movements are taking the lead in removing, among others, names of buildings and streets associated with past surveyors of white supremacy, slavery, and 
colonialism. ${ }^{38}$ Likewise, Black Lives Matter has its duplicates on this side of the Atlantic. These European organizations are contesting police brutality against racial minorities and other forms of structural racism, as well as claiming solidarity with their sister organizations in the US and victims of police brutality there. ${ }^{39}$ Similar movements are visible in the non-Western world, particularly Africa. ${ }^{40}$ While these movements have to be evaluated in their own situational contexts, many are connected to their American counterparts-be it through personal networks, language (such as the global adoption of "woke"), tactics, inspiration, and messaging, or simply by taking advantage of the awareness US-based groups have raised-and vice versa. ${ }^{41}$

\section{Making Sense of the Rhymes: Surveying the Academic Field}

While academic interest in race relations and the struggle for black freedom has been fairly consistent, it may be said that scholars' focus has shifted, both preceding and following the societal developments just noted. Although interest in the 'classic' phase of the civil rights movement, the years 1954 to 1965, remains strong, recent scholarship also shows a renewed interest in the ideologies, strategies, (perceived) radicalism, and cultural icons of the late 1960s. Debates on the "long civil rights movement," a concept that was first introduced by Jacquelyn Dowd Hall in 2005, and the influence of "Black Power Studies" as popularized by Peniel E. Joseph in subsequent years have fueled this shift. ${ }^{42}$ Anniversaries of key moments-not just 1968-may also have promoted such popular and scholarly interest through conference themes or publications, such as Black Power 50 (2016) that commemorates the fiftieth year since the slogan gained widespread popularity ${ }^{43}$ These revisionist studies constitute a reconceptualization of Black Power-one that moves away from the traditional interpretation that saw the nonviolent, rights-based movement of the 'classic' civil rights era as the pinnacle of African American activism and considered Black Power as a symptom of its decline and splintering. To reconcile Black Power's heterogeneous objectives and approaches, these revisionist interpretations additionally treat its emergence in a broader framework of black political and cultural nationalism and self-empowerment that started well before and lasted well beyond the late 1960s and beyond the players that earlier scholars tended to confine it to.

21 As Jeffrey Ogbar, one of the earliest proponents of such a new interpretation and contributor to this special edition, argues in Black Power (2004), it were organizations such as the Black Panthers and the Nation of Islam that "did the most to foment the cultural shifts that reconfigured politics and identity in America." ${ }^{44}$ Moreover, thanks to the fact that by the late 1960s, the "masses of black people [...] embraced black power," the movement changed American religion, music, education, and politics "from the bottom up." ${ }^{45}$ Like many of the studies that have come after, Black Power shows that these organizations existed in a complex, and often mutually beneficial, relationship to the older civil rights organizations and influenced other rights-based movements with its forceful call for black self-determination.

More recent studies have added ever more complex and layered understandings of Black Power. In his effort to map this field, Peniel Joseph identifies several strands. Among these are works that develop connections to grassroots mobilization and activist networks in both the North and South or continuities with earlier black 
nationalist movements. Other scholars emphasize the intersections between race and class. This has led some to explore connections to the larger struggle for social and economic justice, including the work of welfare, union, and prison reform activists. Others have foregrounded the tensions between nonviolence and self-defense in black politics and culture, or the influence of Black Power philosophies on campus protests as well as educational reform. The international dimensions of Black Power form another subcategory, as exemplified by the acclaimed African Americans in Ghana (2006) by Kevin Gaines which analyzes the connections between Black Power and anti-colonialism and Pan-African movements. Still others have aimed to foreground the movement's intellectual legacy and practical and political achievements, which have mostly been neglected at the expense of its cultural politics. Or they aim to broaden understanding of some of the movement's key figures and organizations-as does the work of Joe Street, another contributor to this issue, on the Black Panther Party-and to add new, forgotten ones. Such revisions additionally help illuminate larger questions regarding the perceived radicalism of Black Power groups, like Claude Clegg's 2014 characterization of Nation of Islam as a conservative organization. ${ }^{46}$ Finally, genderbased interpretations of developments in the perception of black masculinity as well as the rise of black feminism could be said to constitute a subfield of Black Power Studies in its own right. ${ }^{47}$

As outlined below, scholars are now also moving beyond the Black Power Studies paradigm in order to investigate connections between the (late) 1960s and present-day race relations, while being fully aware that arguments about historical continuities cannot be stretched too far. After all, 2018 is not 1968. Scholars must consider, in Bernard Harcourt's words, how all "practices of revolt" are "situated" in time and locality. ${ }^{48}$ This also goes for the articulations and meanings of freedom, as Sundiata Keita Cha-Jua and Clarence Lang have argued in their insightful critique of the 'long civil rights movement. ${ }^{49}$ Particularly overusing "the Sixties as a persistent historical touchstone," Lang has warned in a different publication, can do more harm than good, as it "has encouraged a poverty of thought about the contemporary challenges we face as citizens, residents, activists, and scholars desiring progressive social change." ${ }^{50}$

Nowadays, as the scholars in the forum Fifty Years Since MLK point out, understanding racial paradigms accordingly must include questions deriving from new realities in a number of areas. Brandon M. Terry and Christian G. Appy point to the influence on black protest of the War on Terror and shifting geopolitics, as technological advances and political capital have strengthened rather than diminished "the U.S. imperial footprint and assertion of military power" on the planet. Among other things, these have altered ideas of American exceptionalism and strengthened racism through a new deference to the military and veterans as "icons of heroic victimhood" who defend the US from seemingly "outrageous and inexplicable attacks from nonwhite countries and cultures." Moreover, the demographic growth, successes, and (perceived) failures of other minority groups, particularly Asians, Latinx, and Muslim people, in recent years should be considered in relation to (changing) interpretations of multiculturalism and black protest. Barbara Ransby and Andrew Douglas meanwhile draw attention to the heightened effects of racial capitalism, referring to the ways in which economic exploitation and racist ideologies justify and reinforce each other, and of the politics of respectability in (re)shaping today's protest culture. Numerous other new developments need to be considered as well, including changed stereotypes of blacks, 
shifts in gender ideology, and the changing socio-economic circumstances of the white working class. ${ }^{51}$

Scholars who aim to connect the (late) 1960s to the present must also take into account that despite actively building on past traditions and networks of activism, many black activists today-faced with new conditions ranging from internal leadership dynamics and untrodden political and judicial terrains to the use of social media-also relish in maintaining generational splits from an older movement. To gain a sense of their unique contributions, some even insist that the modern freedom struggle "isn't your grandfather's civil rights movement." They point among others to the fact that the movements of the past reproduced sexual and gender inequalities within their own ranks and depended on models of charismatic, male leadership that tended to obscure the roles of and specific repressions facing black women and the black LGBTQ community. The organization Black Lives Matter therefore posits the liberation of black queer and trans persons as the crucial factor in reshaping the methods and goals of the black freedom struggle. Simultaneously, the organizational practices of the Student Nonviolent Coordinating Committee and the mentorship of Ella Baker therein are often quoted as being among the primary sources of historical inspiration for activists in the BLM network. ${ }^{52}$

Clearly, a complex collage of real and perceived lessons and failures of the past continues to inform present-day activists and their observers. By extension, in their day-to-day work, political imagination, and sense of agency, Jeanne Theoharis argues, many of today's black activists are impeded by the misuses of 1960s civil rights history regardless, as over time the "scope of its vision has been narrowed in the service of those in power. The diversity of people who conceived, built, and led that struggle has been diminished, in part because their example offers such a potent challenge to where we are today. ${ }^{\prime 3}$ Yet the eerie familiarity between Martin Luther King's insistence that "our very survival depends on our ability to stay awake, to adjust to new ideas, to remain vigilant and to face the challenge of change" ${ }^{24}$ and contemporary calls by BLM and other groups to "stay woke" underscores the necessity of engaging the living past in the present.

Doing so, however, is easier said than done. Considering these 'new realties' together with historical continuities (as well changing understandings of those histories and continuities) leads to complex questions about how we understand the present in relation to the past-and vice versa. Such complexity is compounded by the fact that these questions are not, indeed should not be, a purely academic affair. Scholars, activists, and scholar-activists debate these questions amongst themselves, with family and friends as well as with journalists, politicians, and other commentators. Many voices in these debates furthermore explicitly or implicitly express a desire for unearthing a "useable past," that is, the ways in which understandings of history (academic history writing, but also memory and commemoration) can be employed for political and social ends by framing current realities or in determining a meaningful way forward.

Especially for many activists and scholars desiring progressive social change, recent events, particularly the emergence of BLM and Donald Trump, have rendered a sense of urgency and legitimacy to such endeavors. The activist community for instance has fueled these debates in multiple ways. In them, connections with the (late) 1960s have arisen organically, from 1960s movement veterans insisting on their relevancy for the 
new movement to current activists' needs. Scholar Jeanne Theoharis for example records having countless conversations with such activists and other sympathizers in search of "fuller histories-uncomfortable, sobering histories-that hold a mirror to the nation's past and offer far-reaching lessons for seeing the injustices of our current moment and the task of justice today" to sustain them. ${ }^{55}$ Likewise, social movement historian Robin D.G. Kelley experienced "literally hundreds of students" of all backgrounds "come running to my courses, questioning their liberalism, seeking out more radical critiques of racial capitalism" after having read the work by Ta-Nehisi Coates. ${ }^{56}$ This desire is also visible in the many attempts to '\#ReclaimMLK' staged by contemporary activists to revive the civil rights leader's radical legacy. ${ }^{57}$

Scholars and scholar-activists have followed suit, often in mutually beneficial roles. The last years of Martin Luther King's life are for instance increasingly 'rediscovered' in scholarly publications ${ }^{58}$ at times with the explicit purpose of aiding current activists in reclaiming his fight against the "triple evils of poverty, racism, and militarism" as a meaningful model for today's struggles. Or Dr. King's life is revisited to counter his 'soft' image that has emerged as a result of his 'canonization' and that is often used to critique current protest groups like BLM ${ }^{59}$ Likewise, roughly the past five years have seen a remarkable acceleration in publications that deal with civil rights memory, ${ }^{60}$ the building of black inner-city communities, and fights against racial capitalism and systemic racism, particularly outside the South. ${ }^{61}$ Among these, books and memoirs dealing with police brutality, criminal justice reform, and Black Lives Matter often engage the 1960s to answer larger questions regarding the long-standing animosity between police and black communities, the causes and effects of riots, the (perceived) relationships between race, gender, and crime and the narrative power of such (alleged) interrelations, and (memories of) past protest traditions and struggles. ${ }^{62}$

30 Publication houses and scholars' internal struggles as citizens to understand (and influence) today's world push them further to explore such connections. Theoharis explicitly draws a connection between concern over the Trump presidency with her desire to write her 2018 monograph A More Beautiful and Terrible History: The Uses and Misuses of Civil Rights History, noting how "[w]e need this history more than ever."63 Many contributors to the Fifty Years Since MLK-issue of The Boston Review explicitly or implicitly express similar motivations. Margaret Edds added a special epiloguedramatically entitled " 2016 " - to her book on the mid- $20^{\text {th }}$ century work of the National Association for the Advancement of Colored People (NAACP) on behalf of school desegregation to lament the Trump administration's gutting of school diversity programs and to remind readers of how the NAACP's lessons can inform new activism. ${ }^{64}$ Other scholars and scholar-activists in the field regularly write op-eds on contemporary events, like Russell Rickford, Barbara Ransby, Michelle Alexander, and Peniel Joseph. Michael Eric Dyson even turned his into a book-length publication. ${ }^{65}$

31 Likewise, Professor Clarence Lang published Black America in the Shadow of the Sixties (2015) after the University of Michigan Press specifically requested he develop his "ideas about the contemporary scene." He agreed, having been transformed by his own experiences teaching in prison, witnessing Obama's election, the conservative backlash in his home state Kansas, and the 2014 racial upheavals in Ferguson. His belief that "the field of African American history, if used critically, can be a vital tool both in reinterpreting the recent past and clarifying the political necessities of the early twenty-first century" drive these analyses. As such, he explicitly explores "the impact 
of the Sixties on the cultural symbols and outlooks that influenced black adolescence in the 1980s, young adulthood in the 1990s, and, for many of us, subsequent careers in academe," including his own. Yet he devotes most of his work to the post-1960s rise of neoliberalism and its effect on the black community. This is a matter of professional survival too, he argues, noting how black scholars increasingly work in higher educational institutions devoted to "corporate planning models" and "a neoliberal logic that seeks to erase historical memory itself," including by showing little concern for safeguarding black scholarly professional organizations and institutions. ${ }^{66}$

Lastly, the ways in which the black freedom struggle in the United States is connected to struggles for racial equality around the world, as noted above, also expresses itself internationally in activists' and scholars' interest in the history of the 1960s. Limiting ourselves to the European context, one illustrative example is the 2018 Martin Luther King Day event in Amsterdam that brought together black American and Dutch activists, artists, and scholars to consider race relations in the Netherlands and to reflect on the questions posed in Dr. King's 1967 book Where Do We Go from Here. ${ }^{67}$ Moreover, "[b]lack intellectual infighting" over the relevancy of past lessons for the contemporary black freedom struggle, for example between Coates and Cornel West, has spread from academia into international mainstream media outlets, such as The Guardian. ${ }^{68}$

Questions as to the ways in which such events and incidents initiate or sustain transnational dialogues of black activists may offer fruitful ideas for future research by (European) Americanists. Britta Waldschmidt-Nelson and Marcia Chatelain have noted how predominantly British and German historians have already begun using "the US civil rights movement as a sounding board for comparing and contrasting racial and ethnic tensions among European populations of color." This makes sense, considering that post-World War II growth and activism of black communities in Europe,

naturally led to comparisons to the black civil rights movement in the US.

Additionally, the movement's idealism and commitment to democracy also prompted young Europeans to consider the future of their respective nation's commitment to these principles. ${ }^{69}$

Part of these investigations are several excellent studies focused on the European sojourns of black American movement leaders. ${ }^{70}$ Other promising work is being done by groups like the Black Diaspora and Germany (BDG) network ${ }^{71}$ and scholars working in the growing fields of Black British and Black German Studies and Black European Studies. Nonetheless, many questions remain about the sustained links, both past and present, between black activists and the theories and practices of the black diaspora in the North Atlantic region that warrant future exploration.

In conclusion, the readers of this special issue of the European Journal of American Studies are invited to consider several interrelated questions as they turn to the articles in this volume: How can the events of 1968 and the late 1960s more generally be understood in relation to long-term continuities or fundamental breaks in the history of the black freedom struggle? How do they challenge traditional understandings of racial progress and (radical) black activism both during the 1960s and beyond? How do they enrich our understanding of 1968 activism, including the relationship of Black Power to a host of other movements-old and new, domestic an international, within and outside of the sphere of black activism? Finally, what questions and potential answers do they raise about the nature and possible future trajectories of contemporary black activism? 


\section{Race Matters: The Articles} of cultural and political activism in 1968 and explicitly engage questions of continuity, memory, and legacies in the present. By extension, all three provide a window into $21^{\text {st }}$ century black activism and its future trajectory by problematizing notions of racial progress over the past fifty years. Hartmann argues that the US is going through a new era of black athletic activism. Through an analysis of the historic Olympic protest of 1968 and 21st century black athletic activism, he contextualizes and deepens our understanding of the unique features of this new wave of activism and its broader societal and theoretical significance. His comparative analysis accordingly sheds light on how and why today's activist athletic movement is the biggest of its kind in American history and on what its strengths and shortcomings are. 

wing of the Black Power movement. Focusing especially on black artistic creativity on television, he traces BAM's influence through time. Ogbar shows that an explosion of black artistic expression in the $21^{\text {st }}$ century exceeds the depth and reach of BAM while still adhering to its fundamental political sensibilities. Visser-Maessen illuminates the ways in which 21st century black activists have used the almost universal whitewashing of Martin Luther King's radical legacy after his 1968 assassination to their advantage. She analyses the elements of King's legacy that American black activists have sought to retrieve during the \#ReclaimMLK campaigns as a window into the heart of what these activists aim to achieve and what obstacles and openings they see in getting there. To spur the aforementioned question of the ways in which the black freedom struggle in the US is connected to struggles for racial equality in Europe, she also zooms in on the way current black activists in western Europe, particularly in the United Kingdom and the Netherlands, use King legacy projects to advocate and justify anti-racism activism in their own, allegedly 'color-blind' societies. She demonstrates how these European activists follow their American counterparts in selectively tying King legacy projects to his final years and the 'sanitization' of his legacy, as this advances their specific goals best. She thereby underscores how $21^{\text {st }}$ century local race relations indeed must be understood in a larger framework that incorporates wider global and historical issues, forces, and trends.

41 However, as Jacquelyn Dowd Hall has argued, the black freedom struggle must be understood in conjunction with what she calls the "long backlash." 72 The final group of articles therefore explores white conservatives' responses to black activism and features contributions by Dr. Rebecca Brückmann and Dr. Maarten Zwiers. Brückmann analyzes the continuing grassroots activism of Citizens' Councils in Louisiana after the 1964 Civil Rights Act. She analyzes the compatibilities between Massive Resistance and the surge of conservatism at the end of the 1960s. Her work demonstrates how these movements were mutually reinforcing through a much needed local case study of how the New Right depended on the infrastructure, culture, and traditions established by older, white supremacist groups and how the latter in turn adapted theirs to those of the former. As such, her work serves as a worthwhile reminder for scholars to view $21^{\text {st }}$ century resistance to black activism not just through a contemporary prism, but in relation to a longer history of white supremacist movement and specifically through its conversion with the conservative movement in the late 1960s.

Finally, Zwiers builds on recent research into the role of emotions in politics to offer a new interpretation of the white backlash against liberal reforms in the late 1960s. Through an intersectional analysis of the role of race, class, and gender in the 1968 presidential campaign, Zwiers demonstrates how the politics of emotion explain George Wallace's strong showing in that race-setting the stage for a style of conservative politics and rhetoric rooted in masculine authoritarianism that has proven to be effective until this day. It thus complements Brückmann's findings on the importance of the South and of the 1960s convergence of white supremacist, conservative, and populist movements for understanding today's right-wing movement at a local and national level.

43 Together, these articles tie in with the need for current scholarship to aid in telling that "more robust and fuller history we need for today." ${ }^{73}$ In the insightful issue Fifty Years Since MLK, Brandon M. Terry has emphatically argued to let "the weight of the 
past" indeed serve as "an aid, not an obstacle, to understanding new features of our racial order." 74 It is our hope that this special issue of The European Journal of American Studies helps towards realizing this vital imperative.

Ella Baker, John Carlos, Stokely Carmichael (Kwame Turé), Hillary Clinton, Ta-Nehisi Coates, Alicia Garza, Henry Louis Gates, Colin Kaepernick, Martin Luther King, Jr., Beyoncé (Knowles), Huey P. Newton, Richard M. Nixon, Barack Obama, Tommie Smith, Donald Trump, Mark Twain, George Wallace, Cornel West.

\section{NOTES}

1. For a sample of recent work on the global contours of the revolution year, consult: Chen Jian et al., eds., The Routledge Handbook of the Global Sixties: Between Protest and Nation Building (New York: Routledge, 2018).

2. Giles Scott-Smith, "We Are All Undesirables: May 68 and Its Legacy," European Journal of American Studies 3:2 (2008): http://journals.openedition.org/ejas/2802. For recent approaches to the study of the 1960s, also consult n1.

3. Thomas Sugrue, Not Even Past: Barack Obama and the Burden of Race (Princeton and Oxford: Princeton University Press, 2010), 1.

4. Barack Obama, “A More Perfect Union” (speech, Philadelphia, 18 March 2008) Constitution Center, https://constitutioncenter.org/amoreperfectunion/docs/Race_Speech_Transcript.pdf; Barack Obama, "Remarks by the President at the 50th Anniversary of the Selma to Montgomery Marches" (speech, Selma, 7 March 2015), White House, http://go.wh.gov/JW2E9T.

5. Jeanne Theoharis, A More Beautiful and Terrible History: The Uses and Misuses of Civil Rights History (Boston: Beacon Press, 2018), xii-xiv, 8-13, 19-21, 26-27, quotes on Obama's "ten procent" and "individualized personal responsibility" comments on xiii, 20; Deborah Chasman and Joshua Cohen, "Editors' Note," in Brandon Terry et al., eds., "Forum 5: Fifty Years Since MLK," Boston Review 43.1 (2018): 7; Ta-Nehisi Coates, We Were Eight Years in Power: An American Tragedy (London: Hamish Hamilton, 2017), 299-303. See also: Michael Tesler and David O. Sears, Obama's Race: The 2008 Election and the Dream of a Post-Racial America (Chicago and London: The University of Chicago Press, 2010); Michael Eric Dyson, The Black Presidency: Barack Obama and the Politics of Race in America (New York: Houghton Mifflin, 2016); Michael Tesler, Post-Racial or Most-Racial?: Race and Politics in the Obama Era (Chicago and London: The University of Chicago Press, 2016).

6. Theoharis, History, ix-xvii, 3-13, 15-22. Quotes on xi, xii, xiii. See also: Coates, Eight Years and Jelani Cobb, The Substance of Hope: Barack Obama and the Paradox of Progress (New York: Walker and Company, 2010).

7. Ruth Milkman, "A New Political Generation: Millennials and the Post-2008 Wave of Protest," American Sociological Review 82:1 (February 2017): 22-25.

8. Keeanga-Yamahtta Taylor, From \#BlackLivesMatter to Black Liberation (Chicago: Haymarket Books, 2016), chapter 5.

9. Coates, Eight Years, 320.

10. Jelani Cobb, "The Matter of Black Lives," New Yorker, 14 March 2016, https:// www.newyorker.com

/magazine/2016/03/14/where-is-black-lives-matter-headed . 
11. Dyson, Black Presidency. Quotes on 273, 283, and 276. Dyson emphasizes that Obama is not responsible for Trump's rise.

12. Theoharis, History, xvi.

13. Coates, Eight Years, xiii, 295, 296.

14. Taylor, \#BlackLivesMatter, 19 and 5.

15. For example, a majority of Americans believes that race relations have become worse since the election of Donald Trump: Pew Research Center, "Most Americans Say Trump's Election Has Led to Worse Race Relations in the U.S." (December 2017): http://www.people-press.org/ 2017/12/19/most-americans-say-trumps-election-has-led-to-worse-race-relations-in-the-u-s/.

16. Clarence Lang, Black America in the Shadow of the Sixties: Notes on the Civil Rights Movement, Neoliberalism, and Politics (Ann Arbor: University of Michigan Press, 2015), vii.

17. David L. Chappell, "After the Dream Died: National Memories of the King Assassination and How They Played Out in Subsequent Legislation," in Britta Waldschidt-Nelson, Marcia Chatelain and Sharon Monteith, eds., Staging a Dream: Untold Stories and Transatlantic Legacies of the March on Washington, Bulletin of the German Historical Institute 11 (Washington DC: German Historical Institute, 2015): 149-153.

18. Martin Luther King, Jr., "Beyond Vietnam" (speech, New York, 4 April 1968): https:// kinginstitute.stanford.edu/king-papers/documents/beyond-vietnam; Peniel E. Joseph, Stokely: A Life (New York: Basic Books, 2014), chapters 12-13 and 16.

19. According to James Forman, Jr. and others, black middle class support for law and order policies has contributed to the mass incarceration of people of color and strengthened the 'politics of respectability.' Elizabeth Hinton counters that the number of blacks who "defied the legitimacy of new policing and carceral strategies" remain both larger and underappreciated in this narrative. James Forman, Jr., Locking Up Our Own: Crime and Punishment in Black America (New York: Farrar, Straus and Giroux, 2017); Michelle Alexander, The New Jim Crow: Mass Incarceration in the Age of Colorblindness (New York: The New Press, 2012); Michael Javen Fortner, Black Silent Majority: The Rockefeller Drug Laws and the Politics of Punishment (Cambridge: Harvard University Press, 2015); Elizabeth Hinton, "On Violence and Nonviolence," in Terry et al., "Fifty Years," 51.

20. For Dr. King's "revolution of values," see among others his speech "Beyond Vietnam." See the critique of Samuel Moyn on the role of neoliberalism in the current status quo: Samuel Moyn, "1968 and the Crisis of Liberalism," in Terry et al., "Fifty Years," 92-101.

21. Moyn, “1968," 92-101. Quotes on 92, 94, 98, 100, 101.

22. Alexander, New Jim Crow.

23. Thad Williamson, "The Almost Inevitable Failure of Justice," in Terry et al., "Fifty Years," 112-114.

24. Hinton, "Violence."

25. See for example: Taylor, \#BlackLivesMater, 7, 10; Alexander Nazaryan, "School Segregation in America As Bad Today as it Was in the 1960s," Newsweek, 22 March 2018, https:// www.newsweek.com/2018/03/30/school-segregation-america-today-bad-1960-855256.html;

Simone Pathe, "Today's Racial Wealth Gap is Wider Than in the 1960s," PBS.org, 18 February 2015, https://www.pbs.org/newshour/nation/todays-racial-wealth-gap-is-wider-than-in-the-1960s;

Sharon Austin, "Black Americans Mostly Left Behind By Progress Since Dr. King's Death," The Conversation, 7 February 2018, https://theconversation.com/black-americans-mostly-left-behindby-progress-since-dr-kings-death-89956.

26. Keturah James and Ayana Jordan, "The Opioid Crisis in Black Communities," The Journal of Law, Medicine and Ethics 46:2 (2018): 404-421; Anjali Om, "The Opioid Crisis in Black and White: The Role of Race in Our Nation's Recent Drug Epidemic," Journal of Public Health 40:4 (2018): 614-615.

27. Josie Pickens, "Ferguson: What's Respectability Got to Do With It?" Ebony Magazine, 18 August 2014, https://www.ebony.com/news/ferguson-whats-respectability-got-to-do-with-it-987/; Barbara Reynolds, "I was a civil rights activist in the 1960s. But it's hard for me to get behind 
Black Lives Matter," Washington Post, 24 August 2015, https://www.washingtonpost.com/ posteverything/wp/2015/08/24/i-was-a-civil-rights-activist-in-the-1960s-but-its-hard-for-meto-get-behind-black-lives-matter/?utm_term=.0ab2c9c327a0; Hinton, "Violence," 50.

28. Aziz Rana, “Against National Security Citizenship,” in Terry et al., "Fifty Years," 81-91. Quote on 81-82.

29. Morgan Winsor, “Martin Luther King Jr.'s Granddaughter Tells March for Our Lives Crowd: ‘I have a dream that enough is enough'," ABC News, 24 March 2018, https://abcnews.go.com/US/ martin-luther-king-jrs-granddaughter-tells-march-lives/story?id=53986952.

30. Caroline Framke, "Beyoncé Didn't Just Steal the Super Bowl Halftime Show, She Made It a Political Act," Vox, 7 February 2016, https://www.vox.com/2016/2/7/10934576/beyonce-superbowl-halftime-2016-coldplay; Lisa Respers France, "Why the Beyoncé Controversy Is Bigger Than You Think," CNN, 24 February 2016, https://edition.cnn.com/2016/02/23/entertainment/ beyonce-controversy-feat/index.html; Diana Falzone, "Backlash to Beyonce's Super Bowl Performance Continues to Grow," Fox News, 12 February 2016, http://www.foxnews.com/ entertainment/2016/02/12/backlash-to-beyonce-super-bowl-performance-continues-togrow.html.

31. For example, compare Marquita Gammage, "Pop Culture Without Culture: Examining the Public Backlash to Beyoncé's Super Bowl 50 Performance," Journal of Black Studies 48:8 (2017): 715-731 to Mako Fitts Ward, "Queen Bey and the New Niggerati: Ethics of Individualism in the Appropriation of Black Radicalism,” Black Camera 9:1 (fall 2017): 146-163.

32. Theoharis, History, xiv-xvi, xxi, 17-18, 22-26, 208-209. Quote on page 208.

33. Andrew Cohen, "The FBI's New Fantasy: 'Black Identity Extremists'," Brennan Center, 11 October 2017, https://www.brennancenter.org/blog/fbi-new-fantasy-black-identity-extremists; Khaled A. Beydoun and Justin Hansford, “The F.B.I.'s Dangerous Crackdown on 'Black Identity Extremists'," New York Times, 15 November 2017, https://www.nytimes.com/2017/11/15/ opinion/black-identity-extremism-fbi-trump.html.

34. Taylor, \#BlackLivesMatter, chapter 5.

35. Federal Bureau of Investigations, "2016 Hate Crime Statistics Released," FBI News, 13 November 2017, https://www.fbi.gov/news/stories/2016-hate-crime-statistics; Mark Berman, "Hate Crimes in the United States Increased Last Year, the FBI Says," Washington Post, 13 November 2017, https://www.washingtonpost.com

/news/post-nation/wp/2017/11/13/hate-crimes-in-the-united-states-increased-last-year-thefbi-says

/?utm_term=.65bced64e232; Lois Beckett, "The Year in Nazi Propaganda: Images of White Supremacy in Trump's America," The Guardian, 27 December 2017, https:// www.theguardian.com/media/2017/dec/27/the-year-in-nazi-propaganda-images-of-whitesupremacy-in-trumps-america.

36. Coates, Eight Years, 341-367. Quote on 344, 348.

37. David French, “No, Ta-Nehisi Coates, Trump Isn't 'America's First White President'," National Review, 12 September 2017, https://www.nationalreview.com/2017/09/ta-nehisi-coates-wronghillary-clinton-not-racism-why-donald-trump-president/. Other responses to Coates' article include: Sean Nelson, “Ta-Nehisi Coates's 'First White President' Is Required Reading," Portland Mercury, 7 September 2017, https://www.portlandmercury.com/blogtown/ 2017/09/07/19301536/ta-nehisi-coatess-the-first-white-president-is-required-reading-nomatter-how-sick-you-are-of-dft; Max Sawicky, "Ta-Nehisi Coates and the 'First White President': An Alternate View," Huffington Post, 19 September 2017, https://www.huffingtonpost.com/entry/ ta-nehisi-coates-and-the-first-white-president_us_59c1240ee4b0186c2205c722; Thomas Chatterton Williams, "How Ta-Nehisi Coates Gives Whiteness Power," New York Times, 6 October 2017, https://www.nytimes.com/2017/10/06/opinion/ta-nehisi-coates-whiteness-power.html. 
38. Such movements exist in many European countries, most notably the United Kingdom, France, Germany, the Netherlands, Denmark, Norway, Sweden, and Spain. For an excellent exploration of the Dutch case, which includes contributions by activists on anti-racist campaigns in the Netherlands, consult Melissa F. Weiner and Antonio Carmona Báez, eds., Smash the Pillars: Decoloniality and the Imaginary of Color in the Dutch Kingdom (Lanham: Lexington Books, 2018). Important works on (anti-Black) racism in the Netherlands, with comparisons and references to other national contexts, including the United States, include Philomena Essed, Understanding Everyday Racism: An Interdisciplinary Theory (Newbury Park et al.: Sage Publications, 1991) and Gloria Wekker, White Innocence: Paradoxes of Colonialism and Race (Durham: Duke University Press, 2016).

39. While Black Lives Matter includes formal chapters in several countries around the world, it also aligns with local organizations, which, in turn, adopt some of its rhetoric and strategies to amplify their own message. This can make it difficult to determine the movement's global reach. However, a spate of solidarity marches in 2016 illustrate the movement's international influence. See for example: Sheena McKenzie, "Black Lives Matter Protests Spread to Europe," CNN, 11 July 2016, https://edition.cnn.com/2016/07/11/europe/black-lives-matter-protests-europe/; Morgan Winsor, "Black Lives Matter Protests Go Global, From Ireland to South Africa," ABC News, 13 July 2016, https://abcnews.go.com/International/black-lives-matter-protests-global-ireland-southafrica/story?id=40546549; Susie Armitage, "2016 Was the Year Black Lives Matter Went Truly Global," BuzzFeed, 8 December 2016, https://www.buzzfeed.com/susiearmitage/2016-was-theyear-black-lives-matter-went-global?utm_term=.rwNObBKXE\#.dyJ7mrKnJ.

40. See for example Ryan Lenora Brown and Ahsraf Hendricks, "Why Africans Are Showing Solidarity with Black Lives Matter Movement," Christian Science Monitor, 15 July 2016, https:// www.csmonitor.com/World/Africa/2016/0715/Why-Africans-are-showing-solidarity-with-BlackLives-Matter-movement

41. See n62-64 below.

42. Jacquelyn Dowd Hall, "The Long Civil Rights Movement and the Political Uses of the Past," The Journal of American History 91:4 (March 2005): 1233-1263; Peniel E. Joseph, "Introduction: Toward a Historiography of the Black Power Movement," in idem, ed., The Black Power Movement. Rethinking the Civil Rights-Black Power Era (New York and London: Routledge, 2006), 1-26.

43. Sylviane A. Diouf and Komozi Woodward, eds., Black Power 50 (New York: The New Press, 2016).

44. Jeffrey Ogbar, Black Power: Radical Politics and African American Identity (Baltimore and London: John Hopkins University Press, 2004), 2.

45. Ibid., 196-197.

46. Claude Andrew Clegg, The Life and Times of Elijah Muhammad (Chapel Hill: University of North Carolina Press, 2014).

47. Joseph, "Historiography"; idem, "The Black Power Movement: A State of the Field," The Journal of American History 96:3 (December 2009): 751-776; idem, "Rethinking the Black Power Era," The Journal of Southern History 75:3 (August 2009): 707-716; idem, "Historians and the Black Power Movement," OAH Magazine of History 22:3 (July 2008): 8-15. More recent contributions on the topics mentioned include, respectively: Nico Slate, ed., Black Power Beyond Borders (New York: Palgrave Macmillan, 2012); Martha Biondi, The Black Revolution on Campus (Berkeley: University of California Press, 2014); Russel Rickford, We Are an African People. Independent Education, Black Power, and the Radical Imagination (Oxford: Oxford University Press, 2016); Robyn Spencer, The Revolution Has Come: Black Power, Gender, and the Black Panther Party in Oakland (Durham: Duke University Press, 2016); Ashley Farmer, Remaking Black Power. How Black Women Transformed an Era (Chapel Hill: University of North Carolina Press, 2017).

48. Bernard E. Harcourt, "Sparking King's Revolution," in Terry et al., "Fifty Years," 55. 
49. Sundiata Keita Cha-Jua and Clarence Lang, "The 'Long Movement' as Vampire: Temporal and Spatial Fallacies in Recent Black Freedom Studies," The Journal of African American History 92:2 (spring 2007): 278.

50. Lang, Black America, 120.

51. Brandon M. Terry, "MLK Now," Barbara Ransby, "King in Context," and Christian G. Appy, "Exceptional Victims." All in Terry et al., "Fifty Years," 15-17, 25-26, 29, 32, 104, 105. Quotes taken from Terry and Appy, 29, 104, 105.

52. Alicia Garza, "A Herstory of the \#BlackLivesMatter Movement," The Feminist Wire, 7 October 2014, http://www.thefeministwire.com/2014/10/blacklivesmatter-2/; Cobb, “The Matter." While the diversity of the modern movement should not be dismissed, some regularly cited differences between the millennial generation and previous generations of activists include a shift of focus toward social justice, immigration, and mass-incarceration and a shift of emphasis toward intersectional analysis and decentered organizing. Such differences are noted in the writing of activists, scholars, and journalists: Garza, "Herstory"; Black Youth Project (John Rogowski and Cathy Cohen), "Black Millennials in America. Documenting the Experiences, Voices and Political Future of Young Black Americans," https://assets.documentcloud.org/documents/2504668/ black-millennials-in-america-report.pdf; Cobb, "The Matter"; Milkman, “A New Political Generation”; Mychal Denzel Smith, “How Trayvon Martin's Death Launched a New Generation of Black Activism," The Nation, 27 August 2014, https://www.thenation.com/article/how-trayvonmartins-death-launched-new-generation-black-activism/; Gene Demby, "The Birth of a New Civil Rights Movement," Politico, 31 December 2014, https://www.politico.com/magazine/story/ 2014/12/ferguson-new-civil-rights-movement-113906.

53. Theoharis, History, xxiv and 26.

54. Martin Luther King, Jr., Where Do We Go From Here: Chaos or Community?, $2^{\text {nd }}$ ed. (New York: Bantam Books, 1968), 199-200.

55. Theoharis, History, xvii-xviii.

56. Robin D.G. Kelley, “Coates and West in Jackson," Boston Review, 22 December 2017, http:// bostonreview.net

/race/robin-d-g-kelley-coates-and-west-jackson

57. Consult the article by Laura Visser-Maessen in this issue.

58. For example, see: Russell Rickford, "It's Time to Reclaim the True Martin Luther King," Washington Post, 18 June 2018, https://www.washingtonpost.com/news/made-by-history/wp/ 2018/01/15/its-time-to-reclaim-the-true-martin-luther-king/?noredirect=on\&utm_term=.

35ea61d898d6; Mary Lou Finley et al., eds., The Chicago Freedom Movement: Martin Luther King, Jr. and Civil Rights Activism in the North (Lexington: University Press of Kentucky, 2018); Michael K. Honey, To The Promised Land: Martin Luther King and the Fight for Economic Justice (n.p.: W.W. Norton, 2018); Martin Luther King, Jr. and Cornel West, The Radical King (Boston: Beacon Press, 2016); Asafo Shaka Sekou, The Radical Political Legacy of Martin Luther King, Jr.: A Political Study Guide (Charleston: Createspace, 2015); Alice Faye Duncan and R. Gregory Christie, Memphis, Martin, and the Mountaintop: the Sanitation Strike of 1968 (n.p.: Calkins Creek, 2018); Lewis V. Baldwin and Rufus Burrow, Jr., eds., The Domestication of Martin Luther King, Jr.: Clarence B. Jones, Right-Wing Conservatism, and the King Legacy (Eugene: Cascade Books, 2013); Jennifer J. Yanco, Misremembering Dr. King: Revisiting the Legacy of Martin Luther King, Jr. (Bloomington and Indianapolis: Indiana University Press, 2014); Jason Sokol, The Heavens Might Crack: The Death and Legacy of Martin Luther King, Jr. (New York: Basic Books, 2018); Martin Luther King, Jr. and Michael Honey, “All Labor Has Dignity" (Boston: Beacon Press, 2014); Clayborne Carson, Martin's Dream: My Journey and the Legacy of Martin Luther King, Jr. (New York: Palgrave Macmillan, 2013); Michael Eric Dyson, April 4, 1968: Martin Luther King, Jr.'s Death and the Transformation of America (New York: Basic Civitas Books, 2009). 
59. For example, see the essays in Terry et al., "Fifty Years"; Lang, Black America; Sarah C. Thuesen, "'Everything Changed, but Ain't Nothing Changed': Recovering a Generation of Southern Activists for Economic Justice," Southern Cultures 14.3 (fall 2008): 142-152; Theoharis, History, xv, xix, 3-5, 18, 22-26, 208. See also the article by Laura Visser-Maessen in this volume.

60. In addition to the work of Theoharis and Lang, which have already been cited, examples include: Renee C. Romano and Leigh Raiford, eds., The Civil Rights Movement in American Memory (Athens and London: The University of Georgia Press, 2006); Michael Eric Dyson, Tears We Cannot Stop: A Sermon to White America (New York: St. Martin's Press, 2017) and What Truth Sounds Like: Robert F. Kennedy, James Baldwin, and Our Unfinished Conversation About Race in America (New York: St. Martin's Press, 2018).

61. For example, see: Khalil Muhammad, The Condemnation of Blackness: Race, Crime, and the Making of Modern Urban America (Cambridge: Harvard University Press, 2011); Michael Ezra, The Economic Civil Rights Movement: African Americans and the Struggle for Economic Power (London: Routledge, 2013); Natalie Y. Moore, The South Side: A Portrait of Chicago and American Segregation (New York: St. Martin's Press, 2016); Tommie Shelby, Dark Ghettos: Injustice, Dissent, and Reform (Cambridge and London: Harvard University Press, 2016); Richard Rothstein, The Color of Law: A Forgotten History of How Our Government Segregated America (New York and London: Liveright Publishing, 2017); David G. García, Strategies of Segregation: Race, Residence, and the Struggle for Educational Equality (Oakland: University of California Press, 2018); Andrea Gibbons, City of Segregation: 100 Years of Struggle for Housing in Los Angeles (Brooklyn: Verso, 2018); Richard H. Sander, Yana A. Kucheva and Jonathan M. Zasloff, Moving Toward Integration: The Past and Future of Fair Housing (Cambridge: Harvard University Press, 2018).

62. For example, see: Alexander, New Jim Crow; Cathy Lisa Schneider, Police Power and Race Riots: Urban Unrest in Paris and New York (Philadelphia: University of Pennsylvania Press, 2014); TaNehisi Coates, Between the World and Me (n.p.: Spiegel and Grau, 2015); Jamala Rogers, Ferguson is America: Roots of Rebellion (n.p: Mira Digital Publishing, 2015); Taylor, \#BlackLivesMatter; Mary Canty Merrill, Why Black Lives Matter (Too): A Revolutionary Call to Action (Bloomington: AuthorHouse, 2016); Michael Flamm, In the Heat of Summer: The New York Riots of 1964 and the War on Crime (Philadelphia: University of Pennsylvania Press, 2017); Forman, Jr., Locking Up; Christopher J. Lebron, The Making of Black Lives Matter: A Brief History of an Idea (New York: Oxford University Press, 2017); Wesley Lowery, They Can't Kill Us All: The Story of Black Lives Matter (London: Penguin Books, 2017); Lauri Hillstrom, Black Lives Matter: From a Moment to a Movement (Santa Barbara: Greenwood, 2018); Patrisse Khan-Cullors and asha bandele, When They Call You a Terrorist (New York: St. Martin's Press, 2018); Ryan Lugalia-Hollon and Daniel Cooper, The War on Neighborhoods: Policing, Prison, and Punishment in a Divided City (Boston: Beacon Press, 2018); Sheila Pree Bright, \#1960Now: Photographs of Civil Rights Activists and Black Lives Matter Protests (n.p.: Chronicle Books, 2018); Barbara Ransby, Making All Black Lives Matter: Reimagining Freedom in the $21^{\text {st }}$ Century (Oakland: University of California Press, 2018).

63. Theoharis, History, xxv.

64. Margaret Edds, We Face the Dawn: Oliver Hill, Spottswood Robinson, and the Legal Team That Dismantled Jim Crow (Charlottesville and London: University of Virginia Press, 2016), 323-330.

65. Dyson, Tears.

66. Lang, Black America, ix-xviii. Quotes on pp. xiii, xv, xvi.

67. "Martin Luther King Day 2018: Where Do We Go from Here," http://humanityinaction.nl/ mlk-2018/.

68. Kelley, "Coates and West"; Cornel West, "Ta-Nehisi Coates Is the Neoliberal Face of the Black Freedom Struggle," The Guardian, 17 December 2017, https://www.theguardian.com/ commentisfree/2017/dec/17

/ta-nehisi-coates-neoliberal-black-struggle-cornel-west; German Lopez, "Cornel West's Attacks on Ta-Nehisi Coates, Explained," Vox, 20 December 2017, https://www.vox.com/identities/ 
2017/12/20/16795746/ta-nehisi-coates-cornel-west-twitter; Melvin Rogers, Patrisse Cullors, Carol Anderson, and Shailja Patel, "Ta-Nehisi Coates v Cornel West: Black Academics and Activists Give Their Verdict," The Guardian, 22 December 2017, https://www.theguardian.com/ commentisfree/2017/dec/22/-ta-nehisi-coates-cornel-west-black-academic-activists-debateequality.

69. Marcia Chatelain and Britta Waldschmidt-Nelson, "Introduction: Untold Stories: The March on Washington-New Perspectives and Transatlantic Legacies," in Waldschmidt-Nelson, Chatelain, and Monteith, eds., Staging a Dream, 8.

70. Stephen Tuck, The Night Malcolm X Spoke At the Oxford Union: The Transatlantic Story of Antiracist Protest (Oakland: University of California Press, 2014) and Brian Ward, Martin Luther King In Newcastle Upon Tyne: The African American Freedom Struggle and Race Relations in the North East of England (n.p.: Tyne Bridge Publishing, 2017).

71. See BDG Network, The Black Diaspora and Germany Deutschland und die Schwarze Diaspora (Münster: Edition Assemblage, 2018).

72. Hall, “Long Civil Rights Movement," 1239.

73. Theoharis, History, xviii.

74. Terry, "MLK Now," 16.

\section{ABSTRACTS}

New questions about the legacies of 1968 and the 1960s in general are presenting themselves to us, as scholars and as citizens, ever more urgently. This is particularly true of race and racial struggle, as unresolved race matters from the past poignantly intersect with twenty-first century activism aimed at countering the continued devaluation of black lives. This special issue of The European Journal of American Studies focuses on the black freedom struggle to explore how those "unresolved race matters from the past" weigh down on the present in terms of (dis)continuities in political activism, protest cultures, backlash, and memory and to highlight the ways in which the 1960s continue to inform and inspire explanations of and resistance to the racial status quo in the $21^{\text {st }}$ century. This introduction will explain why and categorize how today's racial landscape has shaped contemporary societal and scholarly interest in the black, and especially radical, activism of 1968 .

\section{INDEX}

Keywords: 1968, black activism, Black Lives Matter, Black Power, Black Power Studies, civil rights history, civil rights movement, Europe, Martin Luther King, Jr., memory, protest culture, United States 


\section{AUTHORS}

\section{JORRIT VAN DEN BERK}

Jorrit van den Berk is an Assistant Professor of North American Studies at Radboud University, Nijmegen, the Netherlands, where his teaching on US history and politics includes classes on the black freedom movement. He has authored several articles on U.S. foreign relations as well as the book Becoming a Good Neighbor among Dictators. The U.S. Foreign Service in Guatemala, El Salvador, and Honduras (Palgrave Macmillan, 2018). His current research focuses on transatlantic relations and diplomacy and the ways in which these intersect with broader social phenomena, including racism and anti-racism.

\section{LAURA VISSER-MAESSEN}

Laura Visser-Maessen is an Assistant Professor of North American Studies at Radboud University, Nijmegen, the Netherlands. She specializes in African American history and civil rights, but her teaching covers a variety of topics related to American history and culture. These range from (auto)biography, literature, and cultural memory to the American political tradition, cultural diplomacy, and racism in the US. Her book Robert Parris Moses: A Life in Civil Rights and Leadership at the Grassroots (University of North Carolina Press, 2016) became a finalist for the Hooks Institute National Book Award 2016. Her current research interests include (memories of) the civil rights movement; 20th and 21st century public school education for racial minorities in the US; the US as a reference culture for European discussions on race, racism, and black activism; Black European Studies; and black autobiography as a tool of activism. 